(C) Dereito Vol.29, n02:29-59 (Xullo-Decembro, 2020) • ISSN 1132-9947

\title{
A LAS CLÁUSULAS DE VENCIMIENTO ANTICIPADO POR IMPAGO DE CUOTAS EN LOS CONTRATOS DE PRÉSTAMO HIPOTECARIO CON CONSUMIDORES A LA LUZ DE LA STS DE 11 DE SEPTIEMBRE DE 2019
}

The early termination clauses due to breach of contract because of nonpayment contributions in mortgage loans with consumers in the light of the 11 September 2019 Spanish Supremes' Court resolution

DOI: http://dx.doi.org/10.15304/dereito.29.2.7099

\section{ANTONIO DUBERT TRILLO}

Graduado en Derecho

Universidad de Santiago de Compostela

Antodu7@gmail.com

\section{Resumen}

El presente trabajo pretende analizar la abusividad de las cláusulas de vencimiento anticipado (en adelante, v.a.) por incumplimiento del pago de cuotas en los contratos de préstamo hipotecario con consumidores, así como las consecuencias, en su caso, de su declaración de nulidad. En concreto, su objetivo central reside en determinar las condiciones en las que esta cláusula puede ser abusiva, así como si el juez, ante una declaración de nulidad de la cláusula, debe sobreseer el asunto o puede sustituirla por una disposición legal de carácter nacional con el fin de proseguir con la ejecución hipotecaria. Es esta una cuestión muy polémica que ha generado un gran debate en el seno de nuestra jurisprudencia y doctrina científica. Fruto de este debate han sido múltiples los pronunciamientos judiciales, tanto del TJUE como del TS español, que han tratado de solucionar un problema con enormes consecuencias para nuestra sociedad.

Palabras clave: Condiciones generales de la contratación; cláusulas abusivas; vencimiento anticipado; préstamo hipotecario; derecho de contratos.

\section{Abstract}

The present research pretends to analyse the abusiveness of the early termination clauses due to breach of contract because of non-payment contributions in mortgage loans with consumers and the consequences of nullity declaration of these clauses. In particular, the central purpose of this task is to determine the legal situations when this clause can be abusive, as well as if the judge must terminate the initiated procedure in this situation or if he can substitute the abusive clause with a legal and national disposition to continue the mortgage execution. This is a very controversial issue that has generated a big debate inside the Spanish and European jurisprudence and legal-scientific doctrine. This whole situation has led to many judicial pronouncements trying to solve the problem both

Recibido: 20/09/2020. Aceptado: 28/12/2020. 
from Supreme Court of Spain and Court of Justice of the European Union which have enormous consequences for our society.

Keywords: General terms and conditions; abusive clauses; early termination clauses; mortgage loan; contract law.

\section{Introducción. La cláusula de vencimiento anticipado como condición general de la contratación en los contratos de préstamo hipotecario. El vencimiento anticipado por impago de cuotas del préstamo}

Antes de entrar en el fondo de esta problemática cuestión es necesario partir de unas nociones generales sobre la cláusula de vencimiento anticipado (en adelante v.a.) como condición general de la contratación (en adelante c.g.c.) Es el momento de explicar, entonces, cómo se articula la cláusula de v.a. en los contratos de préstamo hipotecario, señalar su tipología y exponer cómo funciona ante el impago de cuotas.

En primer lugar, para hablar de una cláusula de v.a. como c.g.c, debe cumplir los requisitos establecidos por el art. 1 LCGC, según el cual: Son condiciones generales de la contratación las cláusulas predispuestas cuya incorporación al contrato sea impuesta por una de las partes, con independencia de la autoría material de las mismas, de su apariencia externa, de su extensión y de cualesquiera otras circunstancias, habiendo sido redactadas con la finalidad de ser incorporadas a una pluralidad de contratos. Por tanto, cuatro son sus características fundamentales: contractualidad, predisposición, imposición y generalidad.

Además, para ser abusiva debe causar un desequilibrio importante en los derechos y obligaciones de las partes en perjuicio del consumidor, tal y como señalan los arts. 82.1 TRLGDCU y 4.2 Directiva 93/13. Por otro lado, y tratándose de la cláusula de v.a., hemos de hacer referencia al art. 82.4 TRLGDCU TRLGDCU, que recoge una lista negra de cláusulas que son siempre abusivas, y que se complementa con el art. 85.4 TRLGDCU que dispone que las cláusulas que autoricen al empresario a resolver anticipadamente un contrato de duración determinada, si al consumidor y usuario no se le reconoce la misma facultad, o las que le faculten a resolver los contratos de duración indefinida en un plazo desproporcionadamente breve o sin previa notificación con antelación razonable

En segundo lugar, para fundamentar la necesidad del v.a. conviene diferenciar entre relaciones de tracto único o instantáneas, y de tracto sucesivo o duraderas. Según DÍEZ-PICAZO «existe una relación instantánea cuando inmediatamente queda extinguida por la realización de la prestación o prestaciones previstas en ellas. En cambio, las duraderas son aquellas cuyo desenvolvimiento supone un período de tiempo más o menos prolongado en el que se van realizando prestaciones periódicas o se ejecuta una prestación continua» ${ }^{1}$. Las relevantes a la hora

${ }^{1}$ DÍEZ-PICAZO, L. y GULLÓN, A. "Las circunstancias de la relación obligatoria", Sistema de Derecho Civil, Volumen II, Tomo I, Madrid, Editorial TECNOS (Grupo Anaya S.A.), 2016. p. 149. 
de hablar del v.a. son las relaciones de tracto sucesivo y, en concreto, las que conlleven prestaciones periódicas, porque suelen estar sometidas a un plazo para su complimiento y puede entrar en juego el art. 1129 CC que contempla los supuestos en que es posible el vencimiento.

No obstante, el TS ha validado que en los préstamos hipotecarios se inserten cláusulas por las que se amplíen los supuestos de pérdida del beneficio del plazo del deudor, reglados en el art. 1129 CC, basándose en la autonomía de la voluntad (art. 1255 CC), que permite a los contratantes establecer los pactos, cláusulas y condiciones que tengan por conveniente, siempre que no sean contrarios a las leyes, a la moral y al orden público ${ }^{2}$. No obstante, la autonomía de la voluntad queda limitada por el impedimento de que las cláusulas sean abusivas. Además, estas cláusulas deben estar inscritas en el Registro de la Propiedad (art. 130 $\mathrm{LH}$ ), por lo que se someten al control de los Notarios y Registradores como encargados de la validez de las escrituras públicas y de su calificación para la inscripción.

En cuanto a la tipología, hay un gran número de cláusulas de v.a. ${ }^{3}$; entre otras, por incumplimiento de la obligación de pagar contribuciones 0 impuestos que graven la finca, por embargo de bienes del prestatario o disminución de su solvencia, por fallecimiento del deudor o fiador, etc; no obstante, la más relevante y la más común es la que permite al acreedor el v.a. por impago de las cuotas del préstamo por parte del deudor.

Estas últimas suelen incardinarse en los contratos de préstamo hipotecario. Se trata de un préstamo, esto es, un contrato por el que una de las partes entrega dinero a la otra con la condición de que esta devuelva otro tanto de la misma especie y calidad ${ }^{4}$ (y sus intereses), garantizado además con una hipoteca para el caso de que el deudor no pueda devolverlo. Generalmente el préstamo lo concede una entidad de crédito con la finalidad de que el consumidor pueda adquirir un inmueble que es el suele quedar gravado con la hipoteca.

En estos negocios, debido al importe elevado del préstamo, la devolución se suele dividir en cuotas que el deudor debe ir pagando conforme a lo que se pacte en el contrato (por lo general, mensualmente). Por ello, con el fin de agilizar la realización de la hipoteca en caso de incumplimiento del deudor se incluyen frecuentemente cláusulas de v.a. a través de las c.g.c. Se pretende evitar así que el acreedor tenga que esperar a que el deudor deje de pagar todas las cuotas para poder reclamar la devolución del préstamo en su integridad o que tenga que acudir a la resolución del contrato con fundamento en el art. 1124 CC. En realidad, se trata de una resolución anticipada del contrato.

Es necesario mencionar que estas cláusulas sí pueden ser objeto del llamado control de contenido, es decir, aquel que se refiere a las c.g.c.

\footnotetext{
${ }^{2}$ ACHÓN BRUÑÉN, Maj. "Análisis de las distintas cláusulas de vencimiento anticipado que se pueden considerar abusivas en las escrituras de hipoteca", Práctica de los tribunales: revista de derecho procesal civil y mercantil, n.0 126, 2017, p. 1.

${ }^{3}$ Siguiendo a ACHÓN BRUÑÉN, MaJ, loc, cit, p. 2.

${ }^{4}$ DíEZ-PiCAZo, L. Y Gullón, A. «11. El préstamo», Sistema de Derecho Civil, Volumen II, Tomo II, Madrid, Editorial TECNOS (Grupo Anaya, S.A.), 2015 p. 162.
} 
que han pasado los controles de transparencia formal y material y, por tanto, son claras y transparentes, pero pueden resultar abusivas por su contenido, conforme a los arts. 3.1 Directiva 93/135 y 82 TRLGDCU. Ello es importante, ya que este control no cabe sobre las cláusulas que se refieran al objeto principal del contrato. Por tanto, para enjuiciar la abusividad de las cláusulas de v.a. debemos decidir previamente si forman parte de ese objeto principal del contrato. Mi opinión es que las cláusulas de v.a. no forman parte del objeto principal de contrato al no regular un elemento esencial de este, sino que sirven para articular una resolución anticipada, obligando a la devolución anticipada total del dinero prestado, por lo que nada obsta para que queden sometidas a este control.

En cualquier caso, esta discusión tiene relativa importancia, pues la cuestión central no es esta, sino si puede o no un préstamo hipotecario en el que se insertó funcionar con la desaparición de esta cláusula, lo que es distinto. Por su importancia, esta cuestión será objeto de estudio más adelante.

Finalmente, como hemos dicho, las cláusulas de v.a. serán abusivas si causan un desequilibrio importante en la posición jurídica y en perjuicio del consumidor, para lo que debemos atender a una serie de criterios legales y jurisprudenciales que se han ido fijando por el TS y, sobre todo, por el TJUE, gran impulsor de nuestra legislación sobre c.g.c. y cláusulas abusivas ${ }^{6}$.

En realidad, los problemas generados por la cláusula que nos ocupa comenzaron a surgir a raíz de la crisis económica del 2008, al producirse un alto número de desempleados que, con anterioridad y animados por la promoción de las ventajas de la adquisición de vivienda, habían contraído préstamos hipotecarios muy elevados, destinados a comprar viviendas, en muchos casos por encima de sus posibilidades. En este contexto se incoaron un número muy alto de ejecuciones hipotecarias basadas en el v.a. que se producían por el mero incumplimiento de cualquiera de las

\footnotetext{
${ }^{5}$ Las cláusulas contractuales que no se hayan negociado individualmente se considerarán abusivas si, pese a las exigencias de la buena fe, causan en detrimento del consumidor un desequilibrio importante entre los derechos y obligaciones de las partes que se derivan del contrato.

${ }^{6} \mathrm{La}$ importancia de las cláusulas de v.a. en los contratos de préstamo hipotecario se pone de manifiesto incluso en el contexto socioeconómico surgido de la crisis del COVID-19 que hizo necesaria la aprobación de varias normas gubernamentales; entre ellas el RD Ley $8 / 2020$, de 17 de marzo, de medidas urgentes extraordinarias para hacer frente al impacto económico y social del COVID-19, reformado por el RD Ley $11 / 2020$, de 31 de marzo, por el que se adoptan medidas urgentes complementarias en el ámbito social y económico para hacer frente al COVID-19; en ambas se regula la posibilidad de una moratoria a los deudores de préstamos hipotecarios concedidos para adquisición de vivienda habitual, siempre y cuando cumplan con unas determinadas condiciones de vulnerabilidad. A lo que aquí interesa, el art. 14.1 RD-Ley 8/2020, modificado por el $11 / 2020$, señala La solicitud de la moratoria a la que se refiere el artículo 12 conllevará la suspensión de la deuda hipotecaria durante el plazo de tres meses y la consiguiente inaplicación durante el periodo de vigencia de la moratoria de la cláusula de vencimiento anticipado que, en su caso, constará en el contrato de préstamo con garantía hipotecaria. La duración de la suspensión podrá ser ampliada por Acuerdo del Consejo de Ministros.
} 
cuotas que componían el préstamo, lo que produjo dudas sobre la validez de esta cláusula?.

\section{DESARROLLO. 2.1. La abusividad de las cláusulas de vencimiento anticipado en los contratos de préstamo hipotecario con consumidores. Su evolución legislativa a la luz de la doctrina y jurisprudencia europea y española. La STJUE de 26 de marzo de 2019}

Para abordar la cuestión mencionada en la rúbrica hay que partir de que las cláusulas de v.a. no son per se abusivas. Así lo ha recordado continuamente el TS, por ejemplo, en la STS 04.06.2008 ${ }^{8}$, una de las primeras en la materia, donde se puede leer: «como viene señalando la doctrina moderna atendiendo a los usos de Comercio y vista la habitualidad de dichas cláusulas en la práctica bancaria reciente, existen argumentos para defender la validez de tales estipulaciones, como la convenida, al amparo del principio de autonomía de la voluntad».

No obstante, pueden llegar a ser abusivas, pues la misma sentencia establece que son válidas «cuando concurra justa causa para ello, es decir, cuando nos encontremos ante una verdadera y manifiesta dejación de las obligaciones de carácter esencial contraídas, como puede ser, ciertamente, el incumplimiento por el prestatario de la obligación de abono de las cuotas de amortización de un préstamo» ${ }^{9}$., Este primitivo criterio para fijar la validez de una cláusula de v.a. nos pone en evidencia que no será abusiva mientras concurra una justa causa para su ejercicio.

A nuestro juicio, dicho control inicial ni era efectivo ni garantista para el consumidor. Tampoco para el acreedor, quien no sabía de manera clara cuándo podía ejercitar el v.a. Y es que el criterio de la justa causa ni parece muy técnico ni proporciona seguridad jurídica, pues según el caso y el juez que lo interprete la solución puede variar, al no quedar claro si se puede ejercitar el v.a. por el impago de una, dos, tres o todas las cuotas; en el abanico tan amplio que el argumento del TS abre parece que puede ser por cualquier incumplimiento. No obstante, cabe decir que esa falta de claridad y concreción del TS viene dada por una regulación parca e insuficiente que es la establecida por los arts. 1124 y 1129 CC y 693 LEC, a través de los cuales el TS construye la argumentación anteriormente expuesta.

Según el art. 1129 CC «Perderá el deudor todo derecho a utilizar el plazo: 1. ${ }^{\circ}$ Cuando, después de contraída la obligación, resulte insolvente, salvo que garantice la deuda; $2 .{ }^{\circ}$ Cuando no otorgue al acreedor las garantías a que estuviese comprometido; 3.0 Cuando por actos propios hubiese disminuido aquellas garantías después de establecidas, y cuando por caso fortuito desaparecieran, a menos que sean inmediatamente sustituidas por otras nuevas e igualmente seguras». Se trata de una regla insuficiente

\footnotetext{
${ }^{7}$ Según el ATS 08.08.2017 (Roj: ATS 271/2017) en el período 2009-2015 se incoaron 587.995 procesos de ejecución hipotecaria por v.a.

${ }^{8}$ Roj: STS 2599/2008.

${ }^{9}$ En el mismo sentido la STS 16.12.2009 (Roj: STS 8466/2009).
} 
para solucionar la problemática que abordamos por lo que dicho precepto puede completarse con el art. $1124 \mathrm{CC}$, que permite resolver el contrato a la parte cumplidora para el caso de que la otra no cumpliere lo que le incumbe siendo uno de los remedios del incumplimiento. Sin embargo, más allá de los requisitos que exige dicho artículo, sobre el que se hablará más adelante, para poder aplicarlo es necesario que, como él mismo establece, se trate de un contrato generador de obligaciones recíprocas.

Sobre esta cuestión existió un gran debate jurisprudencial y doctrinal en torno a si el préstamo generaba obligaciones recíprocas, pues tradicionalmente se había considerado al préstamo como un contrato real y unilateral, al asumirse que, mediase interés o no, solo surgían obligaciones para el prestatario ${ }^{10}$. La jurisprudencia ha zanjado el asunto en el sentido de que pueden existir contratos de préstamo consensuales $y$, por tanto, recíprocos; la STS 11.07. 2018 ${ }^{11}$ entiende que «en el préstamo con interés cabe apreciar la existencia de dos prestaciones recíprocas y, por tanto, es posible admitir la posibilidad de aplicar, si se da un incumplimiento resolutorio, el art. 1124 CC. (...) Quien asume el compromiso de entregar el dinero lo hace porque la otra parte asume el compromiso de pagar intereses, y quien entregó el dinero y cumplió su obligación puede resolver el contrato conforme al art. 1124 CC si la otra parte no cumple su obligación de pagar intereses».

No obstante, de acuerdo con la doctrina y jurisprudencia españolas son necesarios otros requisitos para que proceda la resolución el contrato, los cuales se aplicarían al caso concreto de que el prestamista ejercitase el v.a. por el impago de cuotas. Dichos requisitos son: (a) que la incumplida se trate de una obligación sinalagmática, exigible y principal; (b) que el que pida la resolución haya cumplido o esté dispuesto a cumplir lo que le incumbe; (c) que se trate de un incumplimiento esencial; (d) que sea un incumplimiento verdadero y propio ${ }^{12}$.

De todos ellos, el más problemático y determinante es el del incumplimiento esencial. Siguiendo a Díez-Picazo podemos considerar esencial aquel incumplimiento que no permite al contratante obtener aquello que se le debía, frustra sus legítimas expectativas y no permite alcanzar la finalidad perseguida por el contrato o su fin económico y social ${ }^{13}$. Partiendo de esa idea, el impago de una sola cuota no parece que pueda ser considerado como un incumplimiento esencial, aunque sí lo puede ser el impago de un gran número de ellas; por tanto, sin una previsión legal que nos dé una cantidad aproximada de cuotas impagadas o de parte del préstamo no devuelto, tendrían que ser los tribunales los

\footnotetext{
${ }^{10}$ Díez-PiCAZo, L. y GuLLón, A. «11. El préstamo», op, cit, pp. 155 a 157.

${ }^{11}$ Roj: STS 2551/2018.

${ }^{12}$ DíEZ-PICAZO Y PONCE DE LEÓN, L. Fundamentos de Derecho civil patrimonial, II. Las relaciones obligatorias. Sexta Edición, Cizur Menor, Thomson-Civitas, 2008. pp. 816 ss.

${ }^{13}$ Díez-PiCAZO y PONCE DE León, L. Fundamentos de Derecho civil patrimonial, op, cit, pp. 851 ss.
} 
que analizasen en el caso concreto si se trata o no de un incumplimiento esencial. ${ }^{14}$

A la vista de lo anterior, los tribunales a la hora de valorar si la cláusula de v.a. era abusiva debían analizar si se trataba de un incumplimiento esencial, basándose en la gravedad del impago y en si lo que se incumplía era una obligación principal. ${ }^{15}$ Está claro que si uno no paga las cuotas del préstamo está incumpliendo la obligación principal, que es la devolución de lo prestado, pero no lo es tanto que el incumplimiento de una sola de esas cuotas sea constitutivo de un incumplimiento suficientemente grave como para ser calificado de esencial. A todo lo anterior debe añadirse que el TS ha llegado a considerar la resolución como un remedio excepcional (STS 22.07.2008 ${ }^{16}$ ).

Por último, antes de la reforma de la LEC ${ }^{17}$, su art. 693.2 regulaba el v.a. de manera muy parca y abierta, dando la posibilidad de ejercitarlo por el impago de alguna de las cuotas, sin especificar un número concreto ${ }^{18}$. Se exigía que el v.a. se hubiese convenido previamente por las partes y que dicho convenio constase inscrito en el Registro, pero no establecía un criterio por el cual el juzgador debiera o pudiera guiarse a la hora de controlar si la ejecución era ajustada a Derecho o no.

En síntesis, la solución que nos daba el TS adolecía de claras deficiencias. El hecho de que por incumplir cualquiera de las cuotas se puediese ejercitar el v.a. ponía al deudor en una situación de desequilibrio jurídico respecto del prestamista. Tal desequilibrio es vital, pues es el que abre la posibilidad de que la cláusula, cuando no ha sido negociada, pueda ser declarada abusiva a través del antes referido control de contenido ${ }^{19}$.

Esta situación se mantuvo hasta el año 2013; entre el año 2008 en que se dictó la sentencia antes comentada y 2013 se produjo un crecimiento exponencial de vencimientos anticipados por el impago de alguna de las cuotas que componían el préstamo hipotecario debido a la crisis económica. En el año 2011, el Juzgado de lo Mercantil n.o 3 de Barcelona se cuestionó si una cláusula que establecía el v.a. de un préstamo hipotecario a 33 años por el incumplimiento de una sola cuota era desproporcionada respecto a los derechos y deberes de las partes y planteó una cuestión prejudicial al TJUE «para que pueda dar contenido al concepto de desproporción en orden: a) A la posibilidad de vencimiento

\footnotetext{
${ }^{14}$ La jurisprudencia considera en otro tipo de relaciones obligatorias sinalagmáticas que el mero retraso no es suficiente para ejercitar la resolución (SSTS 30.12.2015, Roj: STS 5689/2015, y 25.05.2016, Roj: STS 2292/2016). También considera que el incumplimiento debe serlo de una obligación principal (STS 21.07.2012, Roj: STS 5768/2012).

${ }^{15}$ Aunque no cabe desconocer que puede ser esencial $y$, por tanto, resolutorio, el incumplimiento de determinadas obligaciones accesorias (DÍEZ-PICAZO, 2008, p 866).

${ }^{16}$ Roj: STS 4753/2008.

${ }^{17}$ Por Ley $1 / 2013$, de 14 de mayo, de medidas para reforzar la protección a los deudores hipotecarios, reestructuración de deuda y alquiler social.

${ }^{18}$ En concreto señalaba que Podrá reclamarse la totalidad de lo adeudado por capital y por intereses si se hubiese convenido el vencimiento total en caso de falta de pago de alguno de los plazos diferentes y este convenio constase inscrito en el Registro.

${ }^{19} \mathrm{Cfr}$. supra p. 7.
} 
anticipado en contratos proyectados en un largo lapso de tiempo -en este caso 33 años- por incumplimientos en un período muy limitado y concreto».

Dicha cuestión prejudicial dio lugar a la famosa STJUE 14.03.2013, Asunto Aziz. La influencia de esta sentencia ha sido decisiva, pues fue la causa de la modificación del ya mencionado art. 693.2 LEC con el fin de ajustarlo a la doctrina europea.

En la aludida sentencia, el TJUE comienza recogiendo las dudas planteadas por el Juzgado de lo Mercantil de Barcelona sobre los «elementos constitutivos del concepto de cláusula abusiva», refiriéndose al art. 3 de la Directiva 93/13, en concreto a sus apartados $1^{\circ}$ y $3^{\circ}$. Con ello el TJUE trata de concretar, para las cláusulas de v.a., lo que la Directiva recoge como desequilibrio importante entre los derechos $y$ obligaciones de las partes que se derivan del contrato. Para ello parte del concepto de «desequilibrio importante» planteado de manera general, para cualquier cláusula abusiva, según el cual: «el concepto de desequilibrio importante en detrimento del consumidor debe apreciarse mediante un análisis de las normas nacionales aplicables a la falta de acuerdo entre las partes, para determinar si $-y$, en su caso, en qué medida- el contrato deja al consumidor en una situación jurídica menos favorable que la prevista por el derecho nacional vigente. Asimismo, resulta pertinente a estos efectos llevar a cabo un examen de la situación jurídica en la que se encuentra dicho consumidor en función de los medios de que dispone con arreglo a la normativa nacional para que cese el uso de las cláusulas abusivas».

En segundo lugar, el TJUE define este concepto, en concreto, para la cláusula relativa al v.a., estableciendo los criterios que debe «comprobar especialmente» el juez remitente. En concreto debe comprobar «si la facultad del profesional de dar por vencida anticipadamente la totalidad del préstamo depende de que el consumidor haya incumplido una obligación que revista carácter esencial en el marco de la relación contractual de que se trate, si esa facultad está prevista para los casos en los que el incumplimiento tiene carácter suficientemente grave con respecto a la duración y a la cuantía del préstamo, si dicha facultad constituye una excepción con respecto a las normas aplicables en la materia y si el Derecho nacional prevé medios adecuados y eficaces que permitan al consumidor sujeto a la aplicación de esa cláusula poner remedio a los efectos del vencimiento anticipado del préstamo».

Por tanto, cuatro son, a mi juicio, los aspectos a tener en cuenta:

a) Si se trata del incumplimiento esencial de una obligación en el marco de la relación contractual, lo que supondría analizar si el impago de las cuotas del préstamo constituye 0 no dicho incumplimiento esencial en un contrato de préstamo hipotecario.

b) $\mathrm{Si}$ se trata de un incumplimiento suficientemente grave, dándonos dos pautas para determinar la gravedad, que son la duración del contrato y la cuantía del préstamo.

c) Si la facultad de vencer anticipadamente el préstamo es una excepción con respecto a las normas aplicables a la materia. 
d) Si el Derecho nacional prevé medios adecuados y eficaces que permitan al consumidor sujeto a la aplicación de esa cláusula poner remedio a los efectos del v.a. del préstamo. Esto es, si hay alguna manera de que el consumidor pueda evitar ese v.a.; por ejemplo, permitiendo un preaviso y un plazo prudencial en el que el deudor pueda negociar una reestructuración de la deuda o conseguir medios para pagar lo debido.

Con base en esos criterios, mucho más amplios que los existentes en la legislación y jurisprudencia españolas hasta ese momento, debían los jueces nacionales resolver los asuntos referentes a este tipo de cláusulas. No obstante, tales criterios eran inaplicables sin un cambio en la regulación interna porque, como se ha explicado, no había en esta una cantidad determinada de cuotas cuyo impago implicase el v.a. Para ello se aprobó la Ley 1/2013, de 14 de mayo, de Medidas para reforzar la protección a los deudores hipotecarios, reestructuración de deuda y alquiler social, que modificó el art. 693 LEC.

El citado precepto pasó de establecer la posibilidad de ejercitar el v.a. por el impago de alguno de los plazos a imponer un mínimo, que no podía ser empeorado por pacto entre las partes. En concreto, conforme al reformulado art. 693.2 LEC: 2. Podrá reclamarse la totalidad de lo adeudado por capital y por intereses si se hubiese convenido el vencimiento total en caso de falta de pago de, al menos, tres plazos mensuales sin cumplir el deudor su obligación de pago o un número de cuotas tal que suponga que el deudor ha incumplido su obligación por un plazo, al menos, equivalente a tres meses, y este convenio constase en la escritura de constitución. Se cumplía así con el mandato de la sentencia Aziz, que exigía que para poder determinar la gravedad se atendiese a la duración del préstamo y a su cuantía, al introducirse la necesidad del impago de, al menos, tres plazos mensuales sin cumplir el deudor su obligación de impago o de un número de cuotas tal que suponga que el deudor ha incumplido su obligación por un plazo, al menos, equivalente a tres meses.

Además, el propio artículo 693.30 LEC recogía la posibilidad de que el deudor liberase el bien mediante la consignación de la cantidad exacta que estuviese vencida antes del cierre de la subasta, lo que cumple con el requisito exigido por la sentencia Aziz referido a que el consumidor disponga de los medios adecuados y eficaces que le permitan poner remedio a los efectos del v.a. del préstamo; es más, para la vivienda habitual no se necesita el consentimiento del acreedor, pues se entiende que merece una especial protección.

La STS 18.02.2016 20 aplicó la doctrina STJUE Aziz, además del art. 693.2 LEC. Teniendo en cuenta el ATJUE 11.06.2015, ante el pacto de v.a. en un contrato celebrado con consumidores y siempre que se cumplan las condiciones mínimas establecidas en el art. 693.2, estimó que los tribunales deben valorar en el caso concreto si el ejercicio de la facultad de v.a. por parte del acreedor está justificado, en función de los criterios

\footnotetext{
${ }^{20}$ Roj: STS 626/2016. Antes ya la STS 23.12.2015 (Roj: STS 5618/2015).
} 
fijados en la sentencia Aziz. Por tanto, no sería suficiente con cumplir con el art. 693 LEC, sino que habría de valorar la abusividad de la cláusula en el caso concreto, observando si efectivamente está justificado ese v.a.

Sin embargo, la consecuencia de la declaración de nulidad de la cláusula no sería el sobreseimiento del procedimiento de ejecución hipotecaria, cuya causa decae al ser declarado nulo el v.a. (título de ejecución), sino que el TS consideró que se debía aplicar el art. 693.2 LEC de forma subsidiaria. Fundamenta esta decisión en que la declaración de nulidad del v.a. conllevaría la nulidad de un elemento esencial del contrato y, por tanto, la incapacidad de este de subsistir al frustrarse la garantía hipotecaria que garantizaba el derecho de crédito del acreedor. El hecho de que el contrato no pueda subsistir conlleva el sobreseimiento del procedimiento de ejecución hipotecaria y la remisión del asunto a la vía del procedimiento de ejecución ordinario en el que, según el TS, el deudor hipotecario perdería las garantías que el proceso de ejecución le concede, dejando al consumidor en peor situación que si se continuase con dicho procedimiento de ejecución.

Por consiguiente, el TS sienta la doctrina según la cual ante la nulidad de la cláusula de v.a. si el contrato no pudiese subsistir por afectar a un elemento esencial del mismo, ha de aplicarse subsidiariamente el art. 693.2 LEC. De esta manera, el acreedor podría continuar el procedimiento de ejecución hipotecaria si se hubiese pactado en el contrato el v.a. y se diesen las condiciones mínimas fijadas en el citado precepto rituario, aunque dicha cláusula hubiese sido declarada nula por el tribunal enjuiciador. Por añadidura, se permite al acreedor volver a instar el procedimiento de ejecución hipotecaria en el momento en que cumpla las condiciones del art. 693.2 LEC, aunque en el momento de la declaración de nulidad no se cumpliesen, debiendo entonces esperar a ese momento.

Aunque esta decisión, no exenta de polémica, fue confirmada posteriormente por el STJUE 26.03.2019 (Asunto ABANCA) y por la STS $11.09 .2019^{21}$ un gran número de juristas se ha opuesto a esta doctrina. Con acierto, en mi opinión, lo ha hecho el entonces magistrado Orduña Moreno en un Voto Particular en la propia STS 18.02.2016. Considera el magistrado discrepante que la declaración de nulidad de la cláusula de v.a. es correcta, pero no así sus consecuencias. Sus críticas se focalizan en dos: que la doctrina jurisprudencial de la sentencia de la mayoría infringe el principio de efectividad del art. 6.1 de la Directiva 93/13, en relación con el art. 7 , esto es, infringe la obligación de que las cláusulas abusivas no vinculen al consumidor y de que el sistema sea disuasorio; y que el sobreseimiento del procedimiento de ejecución hipotecaria no es perjudicial para el consumidor, a diferencia de lo que considera el TS.

En cuanto a la primera crítica, ORDUÑA MORENO considera que la sentencia no aplica correctamente la doctrina sentada por la STJUE 30.04.2014 Asunto Kásler, que autoriza al juez a sustituir la cláusula nula por una disposición supletoria de derecho nacional, siempre y cuando se trate de una situación en la que el contrato no pueda subsistir tras la

\footnotetext{
${ }^{21}$ Roj: STS 2761/2019.
} 
supresión de la cláusula abusiva. El TS entendió que el contrato de préstamo hipotecario no podía subsistir si se frustra la garantía hipotecaria que garantiza su cumplimiento, al quedar impedida esta si se declara nulo el vencimiento anticipado por ser imposible ejecutarla. Sin embargo, opina que el Asunto Kásler referente al tipo de interés en un préstamo hipotecario y el asunto ahora enjuiciado son distintos, pues el tipo de interés es un elemento esencial del contrato de préstamo, mientras que el v.a. no lo es, por lo que el contrato puede subsistir sin la cláusula. Así, la sentencia de la mayoría estaría integrando el contrato a través de una disposición de carácter nacional, contraviniendo el Derecho de la UE al incumplirse el citado efecto disuasorio de la Directiva 93/13. Este autor recuerda que la declaración de abusividad conlleva la nulidad de pleno derecho de la cláusula, esto es, su no vinculación. Por lo tanto, la consecuencia de la nulidad tenía que haber sido el sobreseimiento del procedimiento de ejecución hipotecaria.

Además, según él, la sustitución debe realizarse «solo en atención de los intereses y derechos del consumidor», siguiendo el Asunto Kásler, lo que no ocurre aquí, pues la continuación del procedimiento de ejecución hipotecaria siempre es perjudicial para el consumidor, por muchas garantías que le otorgue. Por otra parte, estima que los beneficios de la ejecución hipotecaria que señala la sentencia ${ }^{22}$ pueden ser objeto de aplicación extensiva al juicio declarativo que declare el v.a. de la obligación si se ordena la realización de la garantía hipotecaria que, en última instancia, lleva a la ejecución forzosa del bien hipotecado con sus reglas procesales específicas, aunque no señala cómo se produce esa extensión de las ventajas.

En síntesis, toda la crítica de ORDUÑA se sustenta en la consideración de que el v.a. no es un elemento esencial del contrato, lo que a nosotros nos parece irrelevante por dos razones: porque si lo fuese no cabría el control de contenido, tornándose esta discusión en absurda, y porque lo importante es si el contrato puede subsistir sin la cláusula, adoptando un enfoque objetivo ${ }^{23}$, como veremos.

Por su parte, para ADÁN DOMĖNECH ${ }^{24}$, el acreedor no puede pretender la devolución total del préstamo al ser declarada abusiva la cláusula que sustenta el v.a, aun basándose en el art. 1124 CC; en consecuencia, sólo se debe al acreedor un número concreto de cuotas, que son las que este podrá exigir. Pero, mi opinión es que este autor se equivoca, ya que el ejercicio del art. 1124 CC no se realiza por la previsión del v.a., cuya acción debe ejercitarse en el marco del procedimiento de ejecución hipotecaria (art. 693 LEC). El art. 1124 CC sirve para exigir el cumplimiento del contrato o su resolución, siempre que se den los

\footnotetext{
${ }^{22}$ a) Posibilidad de liberar el bien. b) Pérdida de la posibilidad de reducir la deuda (art. 579 de la LEC). c) Pérdida de la garantía de tasación mínima exigida legalmente. d) Inexistente mayor amplitud de los motivos de oposición en la vía declarativa ante una cláusula abusiva (ADÁN DOMÈNECH, 2018, pp. 5 y 6).

${ }^{23}$ STJUE de 14 de febrero de 2014 (Asunto Perenicová).

${ }^{24}$ ADÁN DOMĖNECH, F. "Defensa del consumidor en los procesos declarativos en los que se ejercita el vencimiento anticipado", Diario La Ley, n. ${ }^{\circ}$ 9152, 2018, pp. 1 a 13.
} 
requisitos doctrinal y jurisprudencialmente establecidos; por tanto, el fundamento de la acción resolutoria puede ser similar al de la cláusula v.a., pero no es el mismo. El fin de la resolución es poner fin a un contrato cuyo cumplimiento por el deudor es inviable o muy difícil, mientras que la finalidad del v.a. es penalizar un incumplimiento esencial del deudor del préstamo del que se infiere que no va a poder pagar. Pero son dos figuras distintas y así lo ha querido nuestro legislador al regular la resolución en el art. 1124 CC y el v.a. en los arts. 1129 CC y 693 LEC. Además, hay que recordar que el v.a. hay que pactarlo, tal y como exige el art. 693 LEC, mientras que la resolución es un remedio del incumplimiento que siempre está disponible para las partes cuando se cumplan las condiciones para su ejercicio.

Ante los argumentos anteriores, cabe recordar lo que dice el TS sobre cómo se deben interpretar las normas cuando estamos ante cgc predispuestas por una de las partes sobre otra que es más débil, particularmente un consumidor. Esto es, «la tutela de los consumidores aconseja evitar interpretaciones maximalistas que (...) tengan como consecuencia paradójica la restricción del acceso al crédito hipotecario y, derivadamente, a la adquisición de vivienda en propiedad». Y es que sería «inadecuado obligar a las entidades prestamistas, ante comportamientos de flagrante morosidad, a acudir en exclusiva a la vía declarativa para obtener la resolución contractual, con cierre a la vía ejecutiva especial legalmente prevista y correlativa obstaculización de la efectividad de la garantía real». Es decir, que sería perjudicial e inconveniente para el mercado y, hasta un tanto absurdo, «obligar a la espera de un incumplimiento total en todos los préstamos vigente a largo plazo que contengan cláusulas de vencimiento anticipado abusivas».

Aun así, este último argumento del alto tribunal tampoco es plenamente convincente porque el ejercicio de la resolución no requiere «incumplimiento total», sino que exige un «incumplimiento esencial», algo que es totalmente distinto. La defensa del consumidor no puede obstaculizar el mercado y tener el efecto de que las entidades bancarias dejen de conceder préstamos, pero tampoco puede suponer que la defensa del mercado lleve a aplicar medidas que aceleren las resoluciones de contratos frente a cualquier incumplimiento; in medio virtus.

Ante esta situación, el TS consideró conveniente formular mediante ATS 08.02.201725 una cuestión prejudicial ante el TJUE ${ }^{26}$. El asunto giraba en torno a un contrato de préstamo hipotecario entre ABANCA y un consumidor que contenía una cláusula de v.a. muy similar, por no decir idéntica, a las que habían sido declaradas abusivas en las ya citadas SSTS 23.12.2015 y 16.02 .2016 .

En la cuestión prejudicial se formulaban dos preguntas:

\footnotetext{
${ }^{25}$ Roj: ATS 271/2017.

${ }^{26}$ Algunos consideran que no era necesaria, dando por sentado que el TJUE no iba a responderla o se iba a limitar a negar ambas preguntas.
} 
1. Si es posible hacer una declaración parcial de abusividad de una cláusula, manteniendo la validez de la parte que no se considera abusiva (blue pencil test).

2. Si es posible sustituir la cláusula de v.a. declarada abusiva por una disposición de Derecho nacional (como el art. 693 LEC) en el caso de que el contrato no pudiese subsistir sin la cláusula declarada nula y si la sustitución operaba en interés del consumidor.

BALLUGUERA ${ }^{27}$, para quien era innecesaria la cuestión prejudicial, se opone también a la que llama doctrina «propredisponente» sentada por el TS en las sentencias ya citadas, pues opina que el hecho de integrar el contrato supondría dejar sin efecto su nulidad. Entiende que la única solución pasa por una «renegociación» por las partes del contrato que permita reparar los efectos de la nulidad, instaurando una nueva cláusula de v.a. que «sea equilibrada, transparente y se sujete a los criterios sobre abusividad de la jurisprudencia europea».

Por otra parte, este autor niega la posibilidad de acudir al art. 1124 CC, al entender que el préstamo no es una relación jurídica recíproca, pues opina que «el asiento de una facultad resolutoria legal del préstamo no está en el art. $1124 \mathrm{CC}$ ni en ningún otro del derecho español» y que los arts. 65 y 83 TRLGDCU prohíben colmar la laguna que deja una cláusula abusiva cuando la integración debe ser en beneficio del predisponente. Sin embargo, en mi opinión no es cierto que no se pueda acudir al art. 1124 CC, pues el TS ha establecido que el préstamo hipotecario es un contrato bilateral en el que cabe la resolución; distinto es si su aplicación perjudica o no al consumidor. Pero, o se ejercita el art. 1124 CC para ver si cabe o no la resolución del contrato, o se atiende a la solución del TS, sustituyendo la cláusula por una disposición nacional reguladora del v.a.

Por su parte, ALFARO ${ }^{28}$, que critica más al TJUE que al TS, considera que obligar al acreedor a ejecutar su garantía solo por la parte impagada, debiendo esperar a que el resto venza, es incorrecto porque parece contrario a lo que pactarían las partes. Opina que en esta situación estamos ante una indicación clara de que el deudor será incapaz de pagar en el futuro, debiendo acudirse al art. 1124 CC para respetar mejor el pacto, resolver el contrato y ejecutar la garantía.

Además, propone utilizar los arts. 1124 y 1129 CC para comparar si existe un reparto equilibrado de los derechos y obligaciones entre las partes, ya que estos preceptos sirven para considerar que «dar por vencido el préstamo en su totalidad y ejecutar la garantía hipotecaria en el procedimiento de ejecución hipotecaria ante cualquier incumplimiento del

\footnotetext{
${ }^{27}$ BALluguera Gómez C. "La cuestión prejudicial sobre el vencimiento anticipado. Integración de cláusulas abusivas y falta de confianza del Supremo en el mercado hipotecario. Comentario del auto TS 8 de febrero 2017", Diario La Ley, n. ${ }^{\circ}$ 8950. 2017, pp. 1 a 10.

${ }^{28}$ ALFARO, J. «El Supremo plantea una cuestión prejudicial al TJUE sobre cláusulas de vencimiento anticipado», Almacén de Derecho, 2017 (https://almacendederecho.org/supremo-plantea-una-cuestion-prejudicial-al-tjueclausulas-vencimiento-anticipado/), pp. 1 a 6.
} 
deudor» no se ajusta a ese equilibro jurídico que se persigue con la defensa de los consumidores; también opina que «si la declaración de nulidad de la cláusula genera una laguna en el contrato (...) hay que cubrir la laguna recurriendo al Derecho supletorio, esto es, a la regla legal que habría sido aplicable a falta de pacto».

En esta situación, y tras la formulación de la cuestión prejudicial por el TS a la que nos hemos referido, que supuso que todos los tribunales conocedores de asuntos similares suspendiesen los procedimientos en espera de la decisiónl TJUE resolvió el asunto mediante la STJUE 26.03.2019 Asunto $A B A N C A$, dando respuesta a las dos preguntas que le había planteado el TS.

En cuanto a la primera pregunta, el TJUE ratificó la prohibición del blue pencil test ${ }^{29}$. El TJUE considera que «el art. 6.1 de la Directiva 93/13 debe interpretarse en el sentido de que se opone a una norma de Derecho nacional que permite al juez integrar dicho contrato modificando el contenido» (SSTJUE 14.06.2012 y 30.04.2014). Debe remarcarse que se refiere a la «modificación» del contenido de la cláusula. Se trata de que el juez no pueda dar un contenido distinto a la misma, ya que dicha facultad pondría en peligro el principio de efectividad y la decisión del juez no sería disuasoria.

Respecto a la segunda pregunta, el TJUE se limita a repetir lo dicho en la STJUE 30.04.2014, Kásler y Karlesné Rábai, pues «tal sustitución de una disposición supletoria de derecho nacional queda plenamente justificada a la luz de la finalidad de la Directiva 93/13. Se ajusta al art. 6.1 de la Directiva $93 / 13$ ya que esta disposición pretende reemplazar el equilibrio formal que el contrato establece entre los derechos y obligaciones de las partes por un equilibrio real que pueda restablecer la igualdad entre estas, y no anular todos los contratos que contengan cláusulas abusivas». En caso contrario, considera el TJUE que el consumidor podría quedar expuesto a consecuencias especialmente prejudiciales, al hacer inmediatamente exigible el pago del importe del préstamo pendiente de devolución, pudiendo exceder esa cuantía la capacidad económica del consumidor.

No obstante, a la hora de valorar si el contrato de préstamo hipotecario puede subsistir sin la cláusula de v.a. el TJUE considera que dicha valoración le corresponde al TS. Solo impone como condición la adopción de un «enfoque objetivo». También le corresponde al TS establecer si la anulación de los contratos de préstamo hipotecario expondría a los consumidores a circunstancias perjudiciales. Además, el TJUE condensa la disyuntiva ante la que se halla el TS de la siguiente manera: «Así, en el caso de anulación de los contratos de préstamo hipotecario, el cobro de los créditos de los bancos deberá tener lugar a través de un procedimiento de ejecución ordinaria, mientras que seguirá siendo aplicable el procedimiento especial de ejecución hipotecaria en caso de que esos contratos se mantengan sustituyendo la cláusula abusiva por la nueva redacción del art. 693.2 de la LEC». Por tanto, el TJUE no dice nada que el

${ }^{29}$ Cfr. p. 28. 
TS realmente no sepa; es más, considera que la valoración de si un procedimiento de ejecución es más beneficioso para el consumidor es algo que debe determinar el tribunal español, lo cual es lógico, pues es una mera cuestión de Derecho nacional al no intervenir aquí ninguna norma ni doctrina de la UE o del TJUE necesitada de interpretación.

Lo que sí le dice el TJUE es que en caso de que se sobreseyese el asunto, la circunstancia de si existe un deterioro de la posición procesal del deudor-consumidor es pertinente a la hora de valorar las consecuencias de la anulación del contrato de préstamo hipotecario. Por tanto, en cierto modo le está dando un parámetro útil para valorar las consecuencias de su decisión. Es más, directamente dice que podría justificar que la jurisprudencia española se inclinase por sustituir las cláusulas abusivas controvertidas por la versión del art. 693.2 LEC posterior a la celebración de los contratos controvertidos en los litigios principales, esto es, por el actual art. 24 LCCI, regulador actual de esta cuestión.

Finalmente, recuerda que, si los tribunales concluyen que los contratos de préstamo hipotecario pueden subsistir perfectamente sin la cláusula de v.a. declarada abusiva y, por tanto, nula, deben abstenerse de realizar la sustitución y sobreseer el asunto, salvo que el consumidor se oponga por considerar que una ejecución hipotecaria le es más favorable que el sobreseimiento.

La decisión sorprendió a muchos. Era coincidente con lo que el TS venía manteniendo, pero contraria a buena parte de la doctrina ${ }^{30}$.

El 3 de julio de 2019 se publicaron tres autos del TJUE aclarando más dudas sobre cuestiones que ya habían sido resueltas en la STJUE 26.03.2019, por lo que el TJUE las decidió resolver mediante auto, siguiendo sus normas de procedimiento.

En el Auto del asunto C-486/16 el TJUE, el más relevante de los tres ${ }^{31}$, trata de profundizar más en la cuestión de cuáles son los factores que el tribunal nacional debe tener en cuenta a la hora de valorar qué es lo menos perjudicial para el consumidor, si sobreseer o sustituir la cláusula por una disposición legal interna. Sin embargo, la cuestión más importante de esta decisión se halla en la solución que da a la pregunta sobre cómo es posible volver a iniciar otra vez el procedimiento de ejecución hipotecaria más tarde si la cláusula ya ha sido declarada abusiva, aun cuando se cumplan las condiciones establecidas por el art. 693.2 LEC debido al paso del tiempo y a la continuación de los impagos; al respecto el TJUE dice que el procedimiento no ha sido incoado basándose en la cláusula declarada abusiva sino en la disposición nacional sustitutiva. Por tanto, el contrato no sólo quedaría salvado para la continuación del procedimiento de ejecución hipotecaria si se dan las condiciones del art. 693.2 LEC, sino también para volver a incoar el procedimiento de ejecución especial más adelante, cuando se cumplan las citadas condiciones, basándose, como título ejecutivo, en esa disposición

\footnotetext{
${ }^{30}$ Cfr. pp. 23 a 29.

${ }^{31}$ Los otros dos autos, de los asuntos C-96/16 y C-176/16, se limitan a ratificar lo contenido en la STJUE 26.03.2019.
} 
legal. De esta manera, el sobreseimiento subsanando el contrato no impediría el hecho de que pudiese reabrirse el procedimiento de ejecución especial; decisión que no se opone al principio de efectividad, ya que, «en tal circunstancia, las consecuencias económicas sufridas por el consumidor no se derivan de la cláusula abusiva, sino del incumplimiento contractual consistente en no satisfacer las cuotas mensuales de amortización, que constituye su obligación esencial en el marco del contrato de préstamo celebrado».

PANTALEÓN ${ }^{32}$ realizó una sólida crítica a esta sentencia; el autor ya había criticado la que él llama «doctrina Kásler» de la STJUE 30.04.2014, Asunto Kásler, de la que había dicho que, mal aplicada, como de hecho ocurrió con la abusividad de las cláusulas de intereses moratorios -aquella que decía que en caso de que este fuese abusivo tendría que ser igual a 0podría conducir a situaciones aberrantes; por ejemplo, que ante el hecho de predisponer una cláusula de v.a. abusiva la entidad de crédito no pudiese poner fin anticipadamente a la relación contractual por muchos incumplimientos graves y numerosos, en términos absolutos y relativos, que se produjesen por parte del consumidor, no quedándole otro remedio más que limitarse a la reclamación judicial las veces que fuesen necesarias del pago de la cuota o cuotas no satisfechas tempestivamente. El autor nos dice que el TJUE fue consciente de esta situación en la STJUE 26.03.2019 y decidió modificar parcialmente la «doctrina Kásler» para establecer la ahora llamada «doctrina Kásler-ABANCA». En concreto, lo que hace el TJUE, según PANTALEÓN, es establecer que para valorar la subsistencia del contrato de préstamo hipotecario sin la cláusula de v.a. es necesario interpretar las normas de Derecho interno adoptando un «enfoque objetivo»; tal interpretación la extrae del apartado 60 de la STJUE 26.03.2019. El apartado 32 de la STJUE Perenicová y Perenic nos dice que se debe utilizar «un enfoque objetivo a la hora de interpretar esta disposición, de manera que (...) la posición de una de las partes en el contrato, en el presente caso el consumidor, no puede considerarse el criterio decisivo que decida sobre el ulterior destino del contrato» y después se remite a los apartados 67 y 68 de las Conclusiones que previamente había hecho públicas sobre este asunto la Abogada General Trstenjak. En el apartado 68 de esas Conclusiones se establece algo tan importante como que «excepcionalmente podría considerarse una nulidad total del contrato cuando pudiera darse por supuesto que el negocio no se habría realizado sin las cláusulas nulas conforme a la voluntad común real o hipotética de ambas partes porque la finalidad o la naturaleza jurídica del contrato ya no sean las mismas». Y añade que el examen de si estos requisitos se cumplen en el caso concreto corresponde al juez nacional».

\footnotetext{
${ }^{32}$ Pantaleón Prieto, F. «La sentencia de la Gran Sala del Tribunal de Justicia sobre cláusulas de vencimiento anticipado abusivas», Almacén de Derecho, 2019 (https://almacendederecho.org/la-sentencia-de-la-gran-sala-del-tribunal-de-justicia-
} sobre-clausulas-de-vencimiento-anticipado-abusivas/) pp. 1 a 12. 
De esta manera, a la hora de valorar si es posible sustituir la cláusula de v.a. cuando esta sea abusiva por una disposición de Derecho nacional, no sólo habría que cuestionarse si un contrato de préstamo hipotecario, con carácter general, puede subsistir sin esa cláusula, sino que se ha de aplicar un «enfoque objetivo» en el caso concreto, de forma que el contrato de préstamo hipotecario no podría subsistir jurídicamente, en ese caso (y no con carácter general) «cuando resulte claro que no se habría celebrado sin la cláusula nula, conforme a la voluntad común real o hipotética de ambas partes, porque la finalidad o la naturaleza jurídica del contrato ya no sean las mismas»33.

El «enfoque objetivo» es vital y la cuestión de si cláusula de v.a. es un elemento esencial del contrato se torna irrelevante. Según SOLER SOLÉ34, no se pueden confundir estas dos cuestiones, ya que una cláusula puede no constituir elemento esencial del contrato, pero ser esencial para su subsistencia conforme al «enfoque objetivo». Además, ya sabemos que si fuese un elemento esencial no cabría el control de contenido.

PANTALEÓN ${ }^{35}$ considera que si no se hubiese completado la «doctrina Kásler» con la «doctrina ABANCA» no hubiera podido aplicarse el art. 1124 CC, pues sería tanto como sustituir una cláusula declarada abusiva por una norma de Derecho nacional que reconoce la facultad de resolver el contrato por incumplimiento esencial. Sin embargo, en mi opinión, PANTALEÓN no acierta, pues ya hemos explicado por qué es erróneo este argumento ${ }^{36}$. Además, el art. 693.2 LEC, con el que lo compara este autor, es una norma que fija las condiciones mínimas que debe cumplir toda cláusula de v.a., por lo que es normal que si el contrato no puede subsistir sin dicha cláusula se acuda a esa misma norma para sustituir la declarada abusiva; además, ese recurso se justifica por la seguridad jurídica que confiere al establecer unas pautas concretas y determinadas y por tratarse de una norma propia del procedimiento de ejecución hipotecaria ${ }^{37}$.

Según PANTALEÓN ${ }^{38}$ debe integrarse el contrato con el art. 1124 CC, interpretando el incumplimiento hoy de acuerdo con el imperativo art. 24 LCCI; nos preguntamos, no obstante, si puestos a integrar el contrato no sería más lógico hacerlo directamente con las condiciones fijadas por el art. 24 LCCI. Hay que recordar que para que exista posibilidad de v.a. las partes tienen que pactarlo de modo expreso. $Y$ ahí es donde se

\footnotetext{
${ }^{33}$ En palabras de PANTAleón Prieto, F. «La sentencia de la Gran Sala del Tribunal de Justicia sobre cláusulas de vencimiento anticipado abusivas», loc, cit, p. 5.

${ }^{34}$ SOlER SOLÉ, G. Vencimiento anticipado y ejecución hipotecaria. Tras la STJUE de 26 de marzo de 2019, la STS de 11 de septiembre de 2019 y la Ley de Contratos de Crédito Inmobiliario, Barcelona, AFERRE EDITOR S.L., 2019. pp. 56 a 60.

35 PANTALEÓN PRIETO, F., «En materia de cláusulas de vencimiento anticipado abusivas», Almacén de Derecho, 2019 (https://almacendederecho.org/en-materia-de-clausulas-devencimiento-anticipado-abusivas/), p. 2.

${ }^{36}$ Cfr. pp. 26 y 27.

${ }^{37}$ Hoy la norma aplicable sería el art. 24 LCCI regla imperativa, muy garantista y que cumple perfectamente con los requisitos establecidos por la sentencia Aziz.

${ }^{38}$ PANTALEón PRIETO, F. "En materia de cláusulas de vencimiento anticipado abusivas", loc, cit, pp. 5 y 6.
} 
fundamenta que si el pacto no se ajusta a la legalidad sea sustituido por las condiciones mínimas que la ley fija para ese tipo de pacto; mientras, el art. 1124 CC es una facultad legal que no hay que pactar y a la que siempre puede recurrir la parte cumplidora de cualquier contrato sinalagmático cuando la otra incurra en incumplimiento resolutorio.

\subsection{La situación de las cláusulas de vencimiento anticipado en los contratos de préstamo hipotecario con consumidores tras la STS 11 de septiembre de 2019. Problemas que pretende solucionar y cuestiones no resueltas}

El 11 de septiembre de 2019 el TS dictó una importante sentencia 39 relativa a las cláusulas de v.a. en los contratos de préstamo hipotecario con consumidores, adoptada por unanimidad en Pleno de la Sala Primera 40 con el fin de zanjar de manera definitiva el debate sobre esta cuestión. Es una sentencia muy didáctica que recoge gran parte de la doctrina y jurisprudencia española y comunitaria que se ha ido generando en los últimos años sobre las cláusulas de v.a. en los contratos de préstamo hipotecario.

Lo primero que hace es analizar la doctrina jurisprudencial sobre el v.a. sentada tanto por el propio TS como por el TJUE, algo que ya hemos hecho nosotros en el epígrafe anterior. A continuación, examina cómo debe el TS asumir la doctrina de la STJUE 26.03.2019. Para ello, el TS resume el contenido de dicha sentencia en cinco premisas:

1. Prohibición del blue pencil test.

2. Que la jurisprudencia del TS sobre la aplicación supletoria de una norma de derecho nacional no es contraria a los arts. 6 y 7 de la Directiva 93/13.

3. Que les corresponde a los tribunales nacionales determinar si el contrato puede subsistir sin la cláusula de v.a abusiva.

4. Que para decidir sobre la subsistencia del contrato debe adoptarse un enfoque objetivo, al hilo del apartado 32 STJUE 15.03.2012 Perenicová y Perenic, incluyendo la remisión de este apartado a los apartados 67 y 68 de las Conclusiones de la Abogada General sobre el mismo asunto.

5. Que únicamente es relevante la postura del consumidor cuando se entienda que el contrato puede subsistir sin la cláusula de v.a.

Además, añade la doctrina del ATJUE 3.07.2019 relativo al Asunto C486/16, que había establecido que era posible despachar ejecución hipotecaria si se cumplían los requisitos del art. 693.2 LEC, aunque en el contrato hubiera una cláusula de v.a. declarada abusiva por sentencia firme. Ello es así porque las consecuencias económicas sufridas por el consumidor no provienen de la cláusula declarada abusiva sino del

\footnotetext{
${ }^{39}$ Roj: STS 2761/2019.

${ }^{40}$ Lo que tiene valor a los efectos de unificación de doctrina y le da valor de jurisprudencia, como señala PARRA LUCÁN, Ma A., "Alcance y valor de la jurisprudencia en el Derecho privado español" Revista electrónica de Direito, febrero, 2017, $\mathrm{n}^{\circ} 1,33$.
} 
incumplimiento contractual consistente en no satisfacer las cuotas mensuales de amortización.

A partir de lo anterior, el TS establece las pautas orientativas que deben seguir los tribunales a la hora de declarar nula una cláusula de v.a. en un contrato de préstamo hipotecario con un consumidor. Lo hace siguiendo la doctrina sentada por las SSTJUE 07.08.2018, Banco Santander $y$ Escobedo Cortés, y 14.03.2019, Dunai, conforme a las cuales los órganos jurisdiccionales superiores de un estado miembro de la UE están facultados, dentro del respeto a la Directiva 93/13, para elaborar determinados criterios que sirvan de guía a los tribunales inferiores a la hora de examinar el carácter abusivo de las cláusulas contractuales.

\subsubsection{Sobre si es posible sustituir la cláusula de v.a. por una disposición de derecho nacional}

Siguiendo las pautas de la STJUE 26.03.2019, el TS comienza analizando si el contrato de préstamo hipotecario puede subsistir sin cláusula de v.a.; para ello, insiste en que es jurisprudencia reiterada ${ }^{41}$ que, «aunque en el contrato de préstamo se incluyen dos figuras jurídicas diferentes, el préstamo (contrato) y la hipoteca (derecho real), ambas son inescindibles y conforman una institución unitaria». Además, recuerda que el TJUE también lo considera como un solo contrato con dos facetas: préstamo y garantía ${ }^{42}$ y así lo hace también el art. 3.1 Directiva 2014/17.

Añade el TS que, si bien es cierto que la declaración de nulidad de la cláusula de v.a. no comporta la desaparición completa de las facultades del acreedor hipotecario, sí conlleva una restricción de la facultad esencial del derecho de hipoteca; la garantía perdería su sentido desnaturalizándose, ya que la causa del préstamo y la de la hipoteca se entrelazan pues ante la obtención por parte del consumidor de un préstamo en condiciones económicas más ventajosas el acreedor debe tener una fuerte garantía real para el caso de impago. Así, sin decirlo expresamente, el TS alude a una cierta reciprocidad entre las partes; anticipa, en cierto modo, que si el contrato fuera solo un préstamo sin la garantía hipotecaria la eliminación de la cláusula de v.a. no impediría la subsistencia del contrato, como se confirmaría meses más tarde. ${ }^{43}$

A partir de lo expuesto, el TS considera que sin la cláusula de v.a. el contrato de préstamo hipotecario no puede subsistir; entiende que, teniendo en cuenta la voluntad común real o hipotética de las partes, el negocio no se habría realizado sin la cláusula nula pues la finalidad o naturaleza jurídica del contrato ya no serían las mismas. Además, aprecia

\footnotetext{
${ }^{41}$ Así SSTS todas de 23.01.2019: 46/2019, Roj: STS 101/2019; 47/2019, Roj: STS 103/2019-; 48/2019, Roj: STS 104/2019; y 49/2019, Roj: STS 105/2019.

${ }^{42}$ Así, STJUE 26.03.2019 y AATJUE 03.07.2019.

${ }^{43}$ La STS 12.02.2020 (Roj: STS 336/2020) sienta que en los contratos de préstamo personal la supresión o expulsión de la cláusula de v.a. abusiva no compromete la subsistencia del contrato, por lo que las consecuencias de la nulidad son distintas que en el préstamo hipotecario. Además, resalta que, a diferencia del préstamo hipotecario, el personal o sin garantía carece de normas legales que regulen la posibilidad del v.a., no solo como pacto, sino como previsión legal.
} 
necesaria la sustitución de la cláusula por la redacción actual del art. 693.2 de la LEC, «pero no en su literalidad, sino conforme a la interpretación de dicho precepto que ya habíamos hecho en las SSTS de 21 de diciembre de 2015 y de 18 de febrero de 2016». Esto es así porque, según el TS, la nulidad del contrato expondría al consumidor a consecuencias especialmente perjudiciales, tales como: «la obligación de devolver la totalidad del saldo vivo del préstamo, la pérdida de las ventajas legalmente previstas para la ejecución hipotecaria o el riesgo de la ejecución de una sentencia estimatoria de una acción de resolución del contrato ejercitada por el prestamista conforme al art. 1124 CC con la consiguiente reclamación del préstamo».

Por lo tanto, según el TS en el caso de los préstamos hipotecarios con cláusulas de v.a. de manera general se cumplen los requisitos que el TJUE establece para poder realizar la tan citada sustitución; estos son: que el contrato no pueda subsistir sin la cláusula y que la nulidad total del contrato conlleve consecuencias especialmente perjudiciales para el consumidor, proporcionando, además, criterios para determinar cuándo es perjudicial esa nulidad para el consumidor. De esta manera, el TS recoge las directrices, si se les quiere llamar así, de la STJUE 26.03.2019 y los AATJUE 03.07.2019 y les da contenido; donde el TJUE había establecido que era competencia de los órganos jurisdiccionales nacionales pronunciarse, el TS se pronuncia y decide.

No obstante, el TS reitera algo muy importante, sobre lo que antes se había manifestado con menor rotundidad ${ }^{44}$ : que no solo deben cumplirse con las condiciones fijadas por el art. 693.2 LEC (en la redacción de la Ley $1 / 2013$ ) sino que, además, «los tribunales deberán valorar, en el caso concreto, si el ejercicio de la facultad de vencimiento anticipado por parte del acreedor está justificado, en función de la esencialidad de la obligación incumplida, la gravedad del incumplimiento en relación con la cuantía y duración del contrato de préstamo y la posibilidad real del consumidor de evitar esas consecuencias». Es decir, que no basta con el art. 693.2 LEC sino que dicha norma debe interpretarse de acuerdo con la doctrina fijada por la STJUE 14.03.2013 (Aziz). En consecuencia, concreta el TS que se trata de una labor de interpretación casuística en la que un elemento orientativo de primer orden será el comprobar si se cumplen o no (ahora) los requisitos del art. $24 \mathrm{LCCI}^{45}$, pues la STJUE 20.09.2018 (Asunto OTP

\footnotetext{
${ }^{44}$ Se había pronunciado así en las SSTS 21.12 .2015 y 18.02.2016.

${ }^{45}$ Según el tenor literal de esta norma:

1. En los contratos de préstamo cuyo prestatario, fiador o garante sea una persona física y que estén garantizados mediante hipoteca o por otra garantía real sobre bienes inmuebles de uso residencial o cuya finalidad sea adquirir o conservar derechos de propiedad sobre terrenos o inmuebles construidos o por construir para uso residencial el prestatario perderá el derecho al plazo y se producirá el vencimiento anticipado del contrato si concurren conjuntamente los siguientes requisitos:

a) Que el prestatario se encuentre en mora en el pago de una parte del capital del préstamo o de los intereses.

b) Que la cuantía de las cuotas vencidas y no satisfechas equivalgan al menos:

i. Al tres por ciento de la cuantía del capital concedido, si la mora se produjera dentro de la primera mitad de la duración del préstamo. Se considerará cumplido este requisito
} 
Bank Nyrt) permite no solo la sustitución de la cláusula declarada abusiva por una disposición de Derecho nacional, sino por una disposición imperativa de Derecho nacional aprobada con posterioridad, como es el caso de esta norma.

La sentencia de 11.09.2019 ha tenido una gran repercusión en nuestra literatura jurídica especializada, que se ha manifestado tanto a favor como en contra.

FERNÁNDEZ-SEIJO ${ }^{46}$ la considera acertada al entender que la cláusula es esencial para la entidad financiera y es un instrumento básico para la economía nacional; cree que la solución no perjudica al consumidor, pues su posición en el procedimiento de ejecución no es peor que en el declarativo. Sin embargo, admite que esto último es discutible, al igual que también lo es la posición contraria. Además, opina que los argumentos que utiliza el TS son acordes con los criterios fijados por el TJUE y sus parámetros, «por lo que las críticas a la decisión del Supremo deben ir parejas a las posibles críticas a las resoluciones del TJUE».

Desde la perspectiva opuesta, la decisión ha sido criticada por autores como SOLER SOLÉ ${ }^{47}$, quien entiende que hay dos requisitos cumulativos para admitir la posibilidad de sustituir la cláusula: que el contrato no pueda subsistir sin ella y que la nulidad total perjudique al consumidor, considera que el caso que nos ocupa no se cumple ninguno.

Respecto del primero, cree que no se dan los parámetros del «enfoque objetivo», que centra en cuatro aspectos: la voluntad del acreedor, la del consumidor, la viabilidad del funcionamiento ulterior del contrato y la naturaleza del mismo. Los dos primeros son casi irrelevantes, siendo esenciales los otros. Por una parte, el contrato subsiste perfectamente sin la cláusula pues el art. 693.1 LEC prevé la posibilidad de iniciar un procedimiento de ejecución hipotecaria por las cantidades debidas ya vencidas y el prestatario deberá seguir abonando las siguientes cuotas, por lo que el préstamo sigue con vida. Además, el acreedor siempre dispone del art. 1124 CC para resolver el contrato cuando se den sus requisitos, ya que el TS permite su aplicación al préstamo. Por otra parte,

cuando las cuotas vencidas y no satisfechas equivalgan al impago de doce plazos mensuales o un número de cuotas tal que suponga que el deudor ha incumplido su obligación por un plazo al menos equivalente a doce meses.

ii. Al siete por ciento de la cuantía del capital concedido, si la mora se produjera dentro de la segunda mitad de la duración del préstamo. Se considerará cumplido este requisito cuando las cuotas vencidas y no satisfechas equivalgan al impago de quince plazos mensuales o un número de cuotas tal que suponga que el deudor ha incumplido su obligación por un plazo al menos equivalente a quince meses.

c) Que el prestamista haya requerido el pago al prestatario concediéndole un plazo de al menos un mes para su cumplimiento y advirtiéndole de que, de no ser atendido, reclamará el reembolso total adeudado del préstamo.

2. Las reglas contenidas en este artículo no admitirán pacto en contrario.

${ }^{46}$ FERnÁNDEZ SEIJO, J.Ma. "Los contextos de la Sentencia del Tribunal Supremo sobre vencimiento anticipado", Revista Jurídica sobre Consumidores y Usuarios, 2019, Núm. Especial. STS de 11 de septiembre de 2019 sobre vencimiento anticipado de los préstamos hipotecarios, octubre 2019, p. 49.

${ }^{47}$ SOLER SolÉ, G. op, cit, pp. 56 a 60. 
la finalidad del préstamo hipotecario se mantiene igualmente sin esta cláusula, pues ésta es una cláusula de riesgo prevista para el incumplimiento, pero la finalidad del préstamo hipotecario es siempre la misma: prestar un dinero a cambio de su devolución con intereses en un plazo muy prolongado de tiempo; es más, el v.a. va precisamente contra esa finalidad al prever la posibilidad de resolverlo en un plazo menor. Puede ser cierto que la voluntad común de las partes fuese pactar ese v.a., pero ello se refiere más bien a la causa del contrato que a la adopción de un «enfoque objetivo», que según la argumentación del TS parece más bien subjetivo.

Respecto del segundo requisito, no tiene claro que el sobreseimiento sea perjudicial para el consumidor, más bien lo contrario, pues al tener que acudir a un proceso declarativo el lanzamiento se demora, siendo esto lo que más interesa a un consumidor desesperado que no puede pagar ni lo va a poder hacer. Además, la demanda basada en el art. 1124 CC no tiene por qué ser estimada siempre. Por otro lado, es posible que se acaben extendiendo las garantías del procedimiento de ejecución hipotecaria al procedimiento de ejecución ordinario $y$, por último, no parece que el proceso declarativo tenga que generar un incremento muy alto de costes para el deudor ${ }^{48}$.

\subsubsection{Sobre las pautas jurisprudenciales.}

Es conveniente aludir a otras cuestiones suscitadas por la sentencia que venimos comentando. Además de resolver la cuestión anterior, el TS decidió establecer, obiter dicta, una serie de pautas jurisprudenciales para los tribunales inferiores que se hallen conociendo de procedimientos de ejecución hipotecaria en los que no se hubiese producido todavía la entrega de la posesión al adquiriente ${ }^{49}$. Debemos dividir dichas pautas en dos grupos: las que son pautas en sentido estricto y la última que no se trata de una orientación sino de una aclaración, que en nuestra opinión implica una interpretación contra legem. En este epígrafe nos referiremos a las primeras, que son las siguientes:

a) «Los procesos en que, con anterioridad a la entrada en vigor de la Ley $1 / 2013$, se dio por vencido el préstamo por aplicación de una cláusula contractual reputada nula, deberían ser sobreseídos sin más trámite».

b) «Los procesos en que, con posterioridad a la entrada en vigor de la Ley $1 / 2013$, se dio por vencido el préstamo por aplicación de una cláusula contractual reputada nula, y el incumplimiento del deudor no reúna los requisitos de gravedad y

\footnotetext{
${ }^{48}$ Sorprende que el TS se limite a enumerar los privilegios procesales, sin concretar en qué medida no disfrutar de ellos puede ser, ya no un perjuicio, sino uno de especial intensidad, como exige el TJUE (SOLER SOLÉ, G. op, cit, pp. 78).

${ }^{49}$ SOLER Solé, G. op, cit, pp. 61-63, ha criticado que el TS se arrogue un carácter cuasi legislador estableciendo unas pautas que pueden considerarse, según el, cuasi legislativas y que se pronuncie sobre futuros procedimientos ejecutivos, cuando estamos en un proceso declarativo.
} 
proporcionalidad antes expuestos, deberían ser igualmente sobreseídos».

c) «Los procesos referidos en el apartado anterior, en que el incumplimiento del deudor revista la gravedad prevista en la LCCI, podrán continuar su tramitación».

d) «Los autos de sobreseimiento dictados conforme a los apartados a) y b) anteriores no surtirán efecto de cosa juzgada respecto de una nueva demanda ejecutiva basada, no en el vencimiento anticipado por previsión contractual, sino en la aplicación de disposiciones legales (ATJUE de 3 de julio de 2019, asunto C-486/16). Solución que no pugna con el art. 552.3 LEC, puesto que no se trata de un segundo despacho de ejecución con fundamento en el mismo título, sino de ejecuciones basadas en diferentes títulos (el contrato, en el primer caso, y la ley en el segundo)».

En síntesis, parece que solo pueden continuar su tramitación aquellos procesos en los que, a pesar de haberse ejercitado el v.a. por aplicación de una cláusula nula, el incumplimiento reúne las condiciones del art. 24 LCCI. Los que no cumplan las condiciones mínimas establecidas por dicha norma deben ser sobreseídos, igual que los procesos anteriores a la Ley 1/2013, sin que el TS ofrezca para tal solución explicación alguna.

Es más, el TS va un paso más allá y establece que si bien es cierto que los procedimientos en los que el incumplimiento no reúna las condiciones del art. 24 LCCI deben ser sobreseídos, es posible volver a incoarlos más tarde mediante demanda ejecutiva cuando se cumplan los requisitos de dicho artículo, ya que no se produce el efecto de cosa juzgada. Según el TS esto es posible porque el título ejecutivo ya no es el contrato al no basarse ya la demanda en una previsión contractual sino directamente en el art. 24 LCCI.

SOLER SOLÉ50 no tiene claro si estas pautas son vinculantes para los demás tribunales, pues la jurisprudencia solo complementa al ordenamiento jurídico (art. $1.6 \mathrm{CC}$ ), por lo que niega que puedan tener carácter de fuente del derecho, por mucho que el TJUE le faculte para fijarlas ${ }^{51}$; más, si estas pautas contradicen una disposición legal como es la DT $1^{\text {a. }} 4^{\mathrm{a}} \mathrm{LCCI}$, de la que hablaremos más adelante.

Por otra parte, GALÁN SANCHEZ ${ }^{52}$, estima que, se considere que la nueva demanda ejecutiva se basa en el mismo título (el contrato), pero cumpliendo los nuevos requisitos exigidos por la norma imperativa (art. 24 LCCI), o lo haga en una disposición legal, la conclusión es la misma: la entidad financiera podrá entablar un nuevo proceso de ejecución aunque se haya sobreseído uno anterior. Sin embargo, la cuestión no es baladí

\footnotetext{
${ }^{50}$ SOLER SOLÉ, G. op, cit, pp. 83 a 85.

${ }^{51}$ SSTJUE 07.08.2018, Banco Santander y Escobedo Cortés (C-96/16 y C-94/17, y 14.03.2019, Dunai (C-118/17).

${ }^{52}$ GaLÁn SÁNCHEZ, M. "Análisis de la Sentencia del Pleno del Tribunal Supremo 463/19, de 11 de septiembre. Vencimiento anticipado. Consecuencias", Revista Jurídica sobre Consumidores y Usuarios, 2019, Núm. Especial. STS de 11 de septiembre de 2019 sobre vencimiento anticipado de los préstamos hipotecarios, octubre 2019 2019, p. 64.
} 
porque la ley no es título ejecutivo y lo cierto es que el art. 552.3 LEC no permite dos demandas ejecutivas basadas en el mismo título.

Al respecto, FERNÁNDEZ-SEIJO ${ }^{53}$ considera que «lo que da fuerza ejecutiva es el título, es decir, la escritura pública intervenida». Es más, cree que esta decisión del TS debe interpretarse conforme al art. 693.2 LEC (en su remisión al art. 24 LCCI), al determinar este artículo cuándo debe entenderse que hay un incumplimiento esencial que justifique el vencimiento del préstamo; no obstante, aprecia que «ese incumplimiento grave solo debe valorarse tras comprobar que se ejecuta en escritura pública debidamente inscrita». Considera que esto responde a un criterio eminentemente práctico, pues obligar al ejecutante a iniciar un procedimiento declarativo ordinario puede ser perjudicial para el consumido, si bien reconoce que el proceso declarativo también tiene alguna ventaja para este.

Para sanar definitivamente la posición del TS en este tema, este jurista trae a colación uno de los argumentos de la sentencia que se remite al ATJUE 03.07.2019 del asunto C-486/16 que establece que «el principio de efectividad del Derecho de la Unión no queda menoscabado, porque conforme al principio de autonomía procesal de los estados miembros, una demanda de ejecución hipotecaria pueda sustentarse en la nueva redacción de una norma legal de carácter imperativo». De ahí la importancia que ya habíamos señalado que tenía este auto.

Por otra parte, sobre esta misma cuestión, netamente procesal, SOLER SOLÉ54 opina que quien abre la puerta a la utilización de la ley como título ejecutivo es el ATJUE 03.07.201955, en el que el TJUE considera que la nueva demanda se basa en el incumplimiento esencial del deudor y no en la cláusula abusiva, esto hace que nos preguntemos si al considerar que las consecuencias económicas que pueda sufrir el consumidor se derivan de su incumplimiento y no de la cláusula abusiva no se está confundiendo la facultad de resolución con el ejercicio de la cláusula de v.a., todo ello con el fin de que la ejecución hipotecaria prosiga. Al respecto, volvemos a recordar que el v.a. tiene que constar en un pacto expreso y no es ni debe ser confundida con la facultad legal del art. 1124 CC. Si la disposición legal está sustituyendo a la cláusula abusiva, nos preguntamos entonces si no se está fundando la demanda en una nueva cláusula de v.a. del contrato a la que ahora se le da el contenido del art. 24 LCCI. Todas ellas son preguntas que quedan en el aire y que son prueba de que este asunto no ha quedado, ni mucho menos, zanjado. No obstante, admitimos que pueda ser el TJUE quien se equivoque y contradiga y no el TS, el cual parece no cuestionar la línea del tribunal europeo.

Lo que sí podemos afirmar, aunque el TS no lo diga así, es que el art. 24 LCCI cumple ahora dos funciones en relación con la cláusula de v.a.: a) una función interpretativa, ya que para saber si la cláusula es nula

\footnotetext{
${ }^{53}$ FernándeZ SeIJo, J.Ma. "Los contextos de la Sentencia del Tribunal Supremo sobre vencimiento anticipado", loc, cit, pp. 50 y 51.

${ }^{54}$ SOlER SolÉ, G. op, cit, pp. 121 a 124.

${ }^{55}$ Sobre cuya importancia ya me he pronunciado anteriormente (Cfr. supra pp. 25 y 26).
} 
debemos observar lo que este artículo establece; b) una función sustitutiva de la cláusula nula, pues faculta al acreedor a incoar de nuevo la ejecución hipotecaria cuando el incumplimiento cumpla las condiciones de esencialidad del art. 24 LCCI.

FERNÁNDEZ-SEIJO56 se refiere a la primera función del art. 24 LCCI para valorar el incumplimiento y apostilla que, aunque el TS no lo diga con precisión, «debe entenderse que el incumplimiento del deudor deberá valorarse al tiempo del despacho de ejecución, no en el momento en el que haya de reanudarse la ejecución». De esta manera, «si el incumplimiento ya era grave en el momento de despacharse ejecución, aunque la cláusula en concreto fuera nula, ese incumplimiento permitía despachar ejecución».

\subsubsection{El art. 24 y la DT.1a. $4^{a}$ LCCI}

Nos detenemos a continuación en la segunda de las orientaciones jurisprudenciales del TS. Esta parece en principio aclaratoria, pues comienza estableciendo que «las disposiciones legales mencionadas en el apartado anterior son las contenidas en la Ley de Contratos de Crédito Inmobiliario, pese a que las resoluciones del TJUE se refieran expresamente al art. 693.2 LEC en la redacción dada por la Ley 1/2013»; es decir, que la sustitución hay que realizarla con el art. 24 LCCI y no con el art. 693.2 LEC.

Sin embargo, la polémica se halla en que la frase reproducida anteriormente continua de esta manera: «y pueda haber alguna discordancia con la disposición transitoria primera 4 a de la Ley 5/2019». EI TS introduce esta coletilla con el fin de justificarse, ya que no es que «pueda haber alguna discordancia» con la DT $1^{a}$. $4^{a}$, sino que, según nuestro parecer, de lo que realmente se trata es de una verdadera interpretación contra legem de esa disposición, aunque el TS trate la cuestión como si fuese algo de ínfima importancia. Estimamos que TS lleva a cabo una aplicación retroactiva de un precepto cuya posibilidad la ley expresamente excluye.

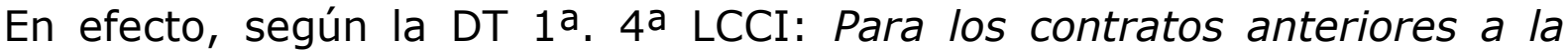
entrada en vigor de esta Ley en los que se incluyan cláusulas de vencimiento anticipado, será de aplicación lo previsto en el artículo 24 de esta Ley, salvo que el deudor alegara que la previsión que contiene resulta más favorable para él. Sin embargo, no será de aplicación este artículo a los contratos cuyo vencimiento anticipado se hubiera producido con anterioridad a la entrada en vigor de esta Ley, se hubiese instado o no un procedimiento de ejecución hipotecaria para hacerlo efectivo, $y$ estuviera este suspendido o no. Es decir, según este texto legal no se puede aplicar el art. 24 LCCI de manera retroactiva a los contratos anteriores a esta ley con una cláusula de v.a. que se hubiera hecho efectiva también con anterioridad a la citada ley. Por tanto, la regla legal

\footnotetext{
${ }^{56}$ Fernández SeIJO, J.Ma. "Los contextos de la Sentencia del Tribunal Supremo sobre vencimiento anticipado", loc, cit, p. 50.
} 
establece una retroactividad limitada que el TS obvia, al considerar aplicable el citado artículo a estas últimas situaciones.

Por si fuera poco, la justificación que el TS aporta al respecto es poco jurídica y bastante farragosa, pues según el TS «La disposición transitoria primera $4^{a}$ LCCI, fruto de una enmienda transaccional en el Congreso y una enmienda en el Senado, optó por la retroactividad limitada para evitar que una sentencia del TJUE contraria al informe del Abogado General en la cuestión prejudicial que había presentado esta sala, pudiera hacer directamente aplicable el 693.2 LEC en su anterior redacción. Por lo que sería contradictorio que la voluntad del legislador se volviera en contra del consumidor, cuando lo que se pretendió es protegerlo más allá de lo previsto en el art. 693.2 LEC anterior a la reforma». Es decir, el TS decide realizar una interpretación teleológica, atendiendo a la hipotética voluntad del legislador, que para colmo presume, pues ni el legislador la expresa ni sabemos de dónde la deriva. Nuestra opinión es que ninguna interpretación teleológica puede sustituir el tenor literal de la ley, pues por mucho que las normas sean interpretables cabe decir que «cuando la ley es clara no hay que acudir a criterios interpretativos complementarios $\gg 57$; y lo cierto es que la DT $1^{a} .4^{a}$ LCCI, guste más o guste menos, dice lo que dice.

Ante esta situación, estamos de acuerdo con SOLER SOLÉ58 cuando afirma que 0 bien nos hallamos ante una interpretación contra legem si entendemos esas orientaciones como jurisprudencia estricta, o bien estamos ante meras orientaciones, de suerte que los tribunales inferiores poseen margen y libertad para no seguirlas. El autor estima que en el caso de que se considere jurisprudencia estricta los tribunales inferiores pueden aplicarla, siguiendo lo establecido en el art. 1.6 CC, o bien no aplicarla, dando prioridad al principio de legalidad (art. 9.3 CE) ${ }^{59}$.

\section{CONCLUSIONES}

Una vez expuesta la evolución legislativa y jurisprudencial sobre la abusividad de las cláusulas de v.a. y sus consecuencias, conviene establecer unas conclusiones en cuanto a si puede considerarse cerrado este asunto tras la STS 11.09.2019, o si seguirá generando problemas.

Para ello es necesario comenzar diciendo que el TS da una respuesta convincente, que puede gustar más o gustar menos, pero que, analizada a la luz de la jurisprudencia del TJUE, se ajusta al Derecho de la UE. Ello es así porque el TS consigue introducir la cláusula de v.a. en la "doctrina Kásler", ahora completada por la "doctrina Abanca"60, al considerar que el contrato de préstamo hipotecario, debido a su naturaleza, la necesita para

\footnotetext{
${ }^{57}$ SOLER SOLÉ, G. op, cit, p. 87.

${ }^{58}$ SOLER SOLÉ, G. op, cit, 87 y 88.

${ }^{59}$ Por su parte, GALÁN SÁNCHEZ, loc, cit, p. 66, trata de interpretar el párrafo citado y extrae la conclusión de que si la aplicación retroactiva del art. 24 LCCI resulta más favorable al consumidor estaría plenamente justificada la decisión, pero no en caso contrario.

${ }^{60}$ Así las llama Pantaleón Prieto, F. «La sentencia de la Gran Sala del Tribunal de Justicia sobre cláusulas de vencimiento anticipado abusivas», loc, cit, pp. 3 a 5.
} 
poder subsistir, al apreciar que, adoptando un "enfoque objetivo", las partes no hubieran contratado sin ella. Además, el TS estima que sin ella la garantía se desnaturaliza y pierde su sentido al ser imposible su realización. Así, en el caso de que la cláusula sea abusiva ésta debe ser sustituida por una disposición de carácter nacional que regule la cuestión (antes el art. 693.2 LEC y ahora el art. 24 LCCI), debiendo proseguir las ejecuciones hipotecarias en las que se cumplan las condiciones establecidas por la disposición sustitutiva.

El problema no está en si la cláusula de v.a. es un elemento esencial del contrato, -a mi juicio no lo es- aunque muchos lo utilicen de argumento para decir que el contrato puede subsistir perfectamente sin ella. El problema se halla en si es un mecanismo necesario para la efectividad de la garantía pactada, y sí lo es, pues está claro que las entidades de crédito no hubieran contratado con el deudor si supiesen que la garantía hipotecaria establecida iba ser imposible de realizar.

Sin embargo, la decisión del TS adolece también de cuestiones sin resolver y de otras que no acaban de convencer, como se ha expuesto más arriba. El defecto principal es la instauración "de facto" de la retroactividad total del art. 24 LCCI en contra de lo establecido por la DT $1^{a}$. $4^{a}$ LCCI, que regula una retroactividad limitada. No solo se halla el defecto en actuar "contra legem", sino en una falta de motivación de la decisión, lo que es destacable, pues ni la fundamentación es muy profunda ni se acaba de comprender, ni es del todo jurídica. Es cierto que la interpretación jurídica no debe alejarse de la realidad social, pero tampoco puede suponer la derogación de una norma y su intercambio por otra creada por el juez, pues ello contradice el art. 9.3 CE, además de socavar la separación de poderes al arrogarse los jueces la cualidad de legisladores. Por otra parte, esta decisión contiene una serie de pautas jurisprudenciales (que son obiter dicta) cuya naturaleza no queda clara, por lo que no sabemos si los juzgados y tribunales inferiores deben seguirlas o pueden desmarcarse de ellas, dando prioridad al principio de legalidad sobre esa interpretación "contra legem".

Más allá de lo anterior, lo cierto es que las cuestiones que quedan sin resolver plenamente son discutibles; no ha quedado claro si el contrato de préstamo puede subsistir sin la cláusula y, sobre todo, si la prosecución de las ejecuciones hipotecarias es más positiva para el consumidor que su sobreseimiento, pues ya se ha expuesto que esto genera dudas en muchos autores. Como se ha puesto de manifiesto, la cuestión de si el préstamo hipotecario puede subsistir sin la cláusula de v.a. depende en buena parte de los intereses que uno defienda. Tan convincente puede resultar el argumento del TS de que el préstamo no subsiste sin ella al quedar impedida la garantía, como el contrario, según el cual el préstamo puede subsistir perfectamente sin el v.a., pues el deudor irá debiendo las cuotas impagadas, y para cuando su incumplimiento sea esencial el acreedor siempre puede acudir al art. 1124 CC, algo que es totalmente cierto pues la resolución es un remedio legal del incumplimiento. Es aquí donde se halla el núcleo principal y, precisamente por ello, para saber si esta doctrina del TS se asienta definitivamente tendremos que esperar a 
las decisiones venideras de juzgados y audiencias provinciales, que en muchos casos habían suspendido los procedimientos. Hay que recordar que el juicio de subsistencia del contrato se ha de llevar a cabo en el caso concreto.

Por otra parte, también están los problemas procesales que debemos tener en cuenta para juzgar si la posición jurídica del consumidor es mejor o peor, derivados de si la ejecución hipotecaria es más beneficiosa que el sobreseimiento, al ofrecer aquella unos beneficios para el deudor que no existen en un proceso declarativo ni en una ejecución ordinaria; también la cuestión de si es posible o no la extensión de las garantías previstas en la ejecución hipotecaria a la ordinaria, como algunos defienden. Otro aspecto procesal importante es si es posible basar una ejecución en la ley y no en el contrato.

La descritas son cuestiones que insinúan que no será la STS 11.09.2019 la última sentencia del TS sobre v.a., pues son muchos los interrogantes que quedan por resolver, especialmente la retroactividad del art. 24 LCCI, si bien en este aspecto el legislador lo podía resolver modificando la problemática DT $1^{a}$. $4^{a}$ para permitir la retroactividad total del art. 24 LCCI. En todo caso, es cierto que el TS ha tomado un camino amparado en la doctrina del TJUE, y que su decisión se encuentra, en mi opinión, dentro de ese marco, pues este dejó en manos del TS la determinación de la subsistencia del contrato sin la cláusula de v.a. Al menos existe ya una postura sobre la no subsistencia del préstamo hipotecario sin el v.a. y una opinión del TS sobre si la continuación de la ejecución hipotecaria es mejor para el consumidor que el sobreseimiento, ambas cuestiones importantes.

Por último, son interesantes las pautas jurisprudenciales finales que da el TS, independientemente de las dudas sobre su naturaleza, pues permiten predecir, en cierto modo, cuáles van a ser las decisiones de los tribunales inferiores y cuál va a ser la posición del TS si tiene que volver a pronunciarse.

Por todo lo anterior, sin obviar las cuestiones que siguen quedando abiertas, no se puede negar que la STS 11.09.2019 ha sido un paso importante y nos acerca a una decisión definitiva que zanje el asunto de las cláusulas de v.a. Es probable que cualquier decisión que el TS adopte genere conflicto, pues las opiniones argumentadas son muchas, es imposible contentar a todos $y$, en buena medida, todo depende de la posición que se quiera tomar y de los intereses que uno defienda, pues hay buenas razones jurídicas para posturas encontradas. En cualquier caso, lo importante es destacar que, más allá de la interpretación "contra legem" de la DT 1a. 4a LCCI, la decisión del TS cabe dentro de la doctrina del TJUE y eso es lo decisivo.

\section{BIBLIOGRAFÍA}

ACHÓN BRUÑÉN, MaJ. «Análisis de las distintas cláusulas de vencimiento anticipado que se pueden considerar abusivas en las escrituras de hipoteca», Práctica de los tribunales: revista de derecho procesal civil y mercantil, 2017, n. ${ }^{\circ} 126, \mathrm{pp}$. 
AdÁN DomèneCH, F. «Defensa del consumidor en los procesos declarativos en los que se ejercita el vencimiento anticipado», Diario La Ley, 2018, n.0 9152, pp. 1 a 13.

Alfaro, J. «Capítulo segundo: El ámbito de aplicación del derecho de las condiciones generales de la contratación», Las condiciones generales de la contratación, Madrid, Editorial Civitas S.A., 1991, pp.111 a 148.

Alfaro, J. «El Supremo plantea una cuestión prejudicial al TJUE sobre cláusulas de vencimiento anticipado», Almacén de Derecho, 2017 (https://almacendederecho.org/supremoplantea-una-cuestion-prejudicial-al-tjue-clausulasvencimiento-anticipado/).

BALluguera Gómez, C. «La cuestión prejudicial sobre el vencimiento anticipado. Integración de cláusulas abusivas y falta de confianza del Supremo en el mercado hipotecario. Comentario del auto TS 8 de febrero 2017», Diario La Ley, 2017, n. ${ }^{0}$ 8950, pp. 1 a 10.

DíEZ-PICAZO Y PONCE DE LEÓN, L. Fundamentos de Derecho civil patrimonial, II. Las relaciones obligatorias. Sexta Edición, Cizur Menor, Thomson-Civitas, 2008.

Díez-PiCAzo, L. y Gullón, A. Sistemas de Derecho Civil, Volumen II, Tomo I, Madrid, Editorial TECNOS (Grupo Anaya S.A.), 2016.

Díez-Picazo, L. y Gullón, A. «11. El préstamo», Sistemas de Derecho Civil, Volumen II, Tomo II, Madrid, Editorial TECNOS (Grupo Anaya, S.A.), 2015, pp. 155 a 157.

FERNÁNDEZ SEIJO, J.Ma., «Los contextos de la Sentencia del Tribunal Supremo sobre vencimiento anticipado», Revista Jurídica sobre Consumidores y Usuarios, 2019, Núm. Especial. STS de 11 de septiembre de 2019 sobre vencimiento anticipado de los préstamos hipotecarios, octubre 2019, pp. 39 a 57.

GALÁn SÁnCHEZ, M., «Análisis de la Sentencia del Pleno del Tribunal Supremo 463/19, de 11 de septiembre. Vencimiento anticipado. Consecuencias», Revista Jurídica sobre Consumidores y Usuarios, 2019, Núm. Especial. STS de 11 de septiembre de 2019 sobre vencimiento anticipado de los préstamos hipotecarios, octubre 2019, pp. 58 a 76.

PANTAleón PRIETO, F. «La sentencia de la Gran Sala del Tribunal de Justicia sobre cláusulas de vencimiento anticipado abusivas», Almacén de Derecho, 2019 (https://almacendederecho.org/lasentencia-de-la-gran-sala-del-tribunal-de-justicia-sobreclausulas-de-vencimiento-anticipado-abusivas/).

PANTALEÓN PRIETO, F., «En materia de cláusulas de vencimiento anticipado abusivas», Almacén de Derecho, 2019 (https://almacendederecho.org/en-materia-de-clausulas-devencimiento-anticipado-abusivas/).

PARRA LUCÁN, Ma A., «Alcance y valor de la jurisprudencia en el Derecho privado español» Revista electrónica de Direito, febrero, 2017, no 1, pp. 1-52. 
SOLER SOLÉ, G., Vencimiento anticipado y ejecución hipotecaria. Tras la STJUE de 26 de marzo de 2019, la STS de 11 de septiembre de 2019 y la Ley de Contratos de Crédito Inmobiliario, Barcelona, AFERRE EDITOR S.L., 2019.

\section{Relación de jurisprudencia empleada:}

\section{Tribunal de Justicia de la Unión Europea.}

STJUE de 3 de junio de 2010, Asunto Caja de Ahorros y Monte de Piedad de Madrid (C-484/08).

STJUE de 15 de marzo de 2012, Asunto Perenicová y Perenic (C-453/10).

STJUE de 14 de marzo de 2013, Asunto Aziz (C-415/11).

STJUE de 30 de abril de 2014, Asunto Kásler y Kaslerné Rábai (C-26/13).

STJUE de 26 de febrero de 2015, Asunto Ofelia Matei (C-143/13).

STJUE de 23 de abril de 2015, Asunto Van Hove (C-96/14).

STJUE de 7 de agosto de 2018, Asunto Banco Santander y Escobedo Cortés (C-96/16).

STJUE de 20 de septiembre de 2018, Asunto OTP Bank Nyrt (C-

STJUE de 14 de marzo de 2019, Asunto Dunai (C-118/17).

STJUE de 26 de marzo de 2019, Asunto ABANCA (Asuntos acumulados C70/17 y C-179/17).

AATJUE de 3 de julio de 2019 (C-486/16, C-92/16 y C-167/16).

\section{Tribunal Supremo.}

STS de 4 de junio de 2008 (Roj: STS 2599/2008 - ECLI: ES:TS: 2008:2599).

STS de 22 de julio de 2008 (Roj: STS 4753/2008 - ECLI: ES:TS: 2008:4753).

STS de 12 de diciembre de 2009 (Roj: STS 8466/2009 - ECLI: ES:TS: 2009:8466).

STS de 16 de diciembre de 2009 (Roj: STS 8466/2009 - ECLI: ES:TS:2009:8466).

STS de 4 de noviembre de 2010 (Roj: STS 6062/2010-ECLI:ES:TS: 2010:6062).

STS de 29 de diciembre de 2010 (Roj: STS 7551/2010-ECLI:ES:TS: 2010:7551).

STS de 2 de marzo de 2011 (Roj: STS 1244/2011-ECLI:ES:TS: 2011:1244).

STS de 12 de diciembre de 2011 (Roj: STS 8850/2011-ECLI:ES:TS: 2011:8850).

STS de 18 de junio de 2012 (Roj: STS 5966/2012-ECLI:ES:TS: 2012:5966).

STS de 21 de julio de 2012, (Roj: STS 5768/2012 - ECLI: ES:TS:2012:5768).

STS de 9 de mayo de 2013 (Roj: STS 1916/2013-ECLI:ES:TS: 2013:1916).

STS de 25 de noviembre de 2015 (Roj: STS 4810/2015 - ECLI: ES:TS: 2015:4810). 
STS de 23 de diciembre de 2015 (Roj: STS 5618/2015 - ECLI: ES:TS: 2015:5618).

STS de 30 de diciembre de 2015 (Roj: STS 5689/2015 - ECLI: ES:TS: 2015:5689).

STS de 18 de febrero de 2016 (Roj: STS 626/2016 - ECLI: ES:TS: 2016:626).

STS 25 de mayo de 2016 (Roj: STS 2292/2016 - ECLI: ES:TS: 2016:2292).

STS de 24 de enero de 2018 (Roj: STS 139/2018 - ECLI: ES:TS: 2018:139).

STS de 11 de julio de 2018 (Roj: STS 2551/2018 - ECLI: ES:TS: 2018:2551).

STS de 23 de enero de 2019 (Roj: STS 101/2019-ECLI:ES:TS: 2019:101). STS de 23 de enero de 2019 (Roj: STS 103/2019-ECLI:ES:TS: 2019:103). STS de 23 de enero de 2019 (Roj: STS 104/2019-ECLI:ES:TS: 2019:104). STS de 23 de enero de 2019 (Roj: STS 105/2019-ECLI:ES:TS: 2019:105). STS de 11 de septiembre de 2019 (Roj: STS 2761/2019 - ECLI: ES:TS: 2019:2761).

STS de 12 de febrero de 2020 (Roj: STS 336/2020-ECLI: ES:TS: 2020:336).

ATS de 8 de febrero de 2017 (Roj: ATS 271/2017 - ECLI: ES:TS: 2017:271A). 